\title{
A Mylohyoid Nerve Traveling Within the Mandibular Canal: a Case Report
}

\author{
Mandibular Kanal İcerisinde Seyreden Nerous Mylohyoideus: Olgu Raporu
}

\author{
Cenk KILIÇ ${ }^{1}$ Kıvanç KAMBUROĞLU, ${ }^{2}$ Tuncer ÖZEN ${ }^{3}$ \\ ${ }^{1}$ Department of Anatomy, Medical Faculty of Gülhane Military Medical Academy; \\ ${ }^{2}$ Department of Oral Diagnosis and Radiology, Faculty of Dentistry, Ankara University; \\ ${ }^{3}$ Department of Oral Diagnosis and Radiology, Dental Science Center of Gülhane Military Medical Academy, all in Ankara
}

Accepted / Kabul tarihi: 26.10.2008

The mylohyoid nerve is a branch of the mandibular division of the trigeminal nerve and travels through mylohyoid groove in the medial side of the mandible. This nerve innervates the mylohyoid muscle and the anterior belly of the digastric muscle. This case report highlights one possible variation in the course of the nerve. In the case presented here, mylohyoid nerve traveled within mandibular canal in the right side of a mandible on routine dissection of a 49-year-old male cadaver. The position of the canal and nerves within the mandible was assessed from dental cone-beam computed tomography images and by dissection after imaging. The right hemi-mandible was cut into eight serial, and the nerve was observed to travel within the mandibular canal in the 5th, 6th and 7th bony slices. The nerve can be damaged during surgical procedures of the mandible such as osteotomy and salivary gland operations. In addition, accessory innervation of anterior and posterior mandibular teeth pulp by sensory components of the mylohyoid nerve is thought to be one reason for the failure of anesthesia of the inferior alveolar nerve. Clinicians should be aware of complications that may arise from a mylohyoid nerve travelling within the mandibular canal.

Key words: Mandible; mylohyoid nerve; inferior alveolar nevre; variation; mandibular injuries.
Nervus mylohyoideus n. trigeminus'un bir dalı olan n. mandibularis'in bir dalıdır ve mandibula iç yüzündeki sulcus mylohyoideus'ta seyreder. $\mathrm{Bu}$ sinir $\mathrm{m}$. mylohyoideus ve $\mathrm{m}$. digastricus'un ön karnını uyarır. Bu olgu raporu sinirin seyrindeki muhtemel bir varyasyona ışık tutar. Burada sunulan olguda, kırk dokuz yaşındaki bir erkek kadavranın rutin diseksiyonu sırasında, n. mylohyoideus mandibula'nın sağ tarafında mandibular kanal içerisinde seyrediyordu. Dental volumetrik tomografi ve görüntüleme sonrası diseksiyon ile mandibula içerisindeki kanalın ve sinirlerin pozisyonu değerlendirildi. Sağ yarım mandibula'ya sekiz seri halde kesit uygulandı ve sinirin beşinci, altıncı ve yedinci kesitlerde mandibular kanal içerisinde seyrettiği gözlendi. Sinir osteotomi ve tükürük bezi operasyonları gibi mandibula'nın cerrahi işlemleri esnasında hasar görebilir. Ek olarak, n. mylohyoideus'un duyu içeren dalları tarafından ön ve arka diş pulpalarının aksesuar sinir desteğinin $\mathrm{n}$. alveolaris inferior'un anestezisinin yetersizliğinin sebeplerinden biri olabileceğini düşündürür. Klinisyenler mandibular kanal içerisinde seyreden bir $\mathrm{n}$. mylohyoideus'un bulunmasından kaynaklanabilecek olan komplikasyonların farkında olmalıdırlar.

Anahtar sözcükler: Mandibula; nervus mylohyoideus; nervus alveolaris inferior; varyasyon; mandibular yaralanmalar.

Correspondence (IIletişim adresi): Dr. Cenk Kılıç. Gülhane Askeri Tıp Akademisi Anatomi Anabilim Dalı, 06010 Ankara.

Tel: 0312 - 3046666 e-mail (e-posta): ckilicmd@yahoo.com

(c) Trakya Üniversitesi Tıp Fakültesi Dergisi. Ekin Tıbbi Yayıncıık tarafından basılımıstır. Her hakkı sakıdır.

(c) Medical Journal of Trakya University. Published by Ekin Medical Publishing. All rights reserved. 
The mylohyoid nerve originates as a branch of the inferior alveolar nerve before the latter enters the mandibular foramen. The mylohyoid nerve is considered to be primarily a motor nerve carrying efferent information to the mylohyoid muscle and the anterior belly of the digastric muscle. The mylohyoid nerve usually travels through the mylohyoid groove located in the medial side of the mandible. ${ }^{[1]}$ However, transition of the mylohyoid groove into a partially or fully osseous canal has been previously reported..$^{[2,3]}$

The mylohyoid nerve can be damaged during surgical procedures of the mandible such as osteotomy and salivary gland operations. Moreover, accessory innervation of mandibular anterior and posterior teeth pulp by the mylohyoid nerve's sensory components is thought to be one reason for failure in the anesthesia of the inferior alveolar nerve. ${ }^{[4-7]}$ Therefore, it is important for the clinician to be aware of variations in the mylohyoid groove and in the position and course of the mylohyoid nerve within this groove.

\section{CASE REPORT}

In this case study, routine dissection of the mandible of a 49-year-old male cadaver found the mylohyoid nerve traveled within the mandibular canal on the right side (Figs. 1-3). The position of the canal and the nerves within the mandible was assessed from dental conebeam computed tomography images (Imtec Imaging, Ardmore, OK, US) (Fig. 2a) and by dissection after imaging. Using a low speed diamond saw (Model 650 South Bay Tech. California, USA), the right hemi-mandibular specimen was sectioned at 8 serial sites and 7 bony slices were obtained (Figs. 2b, 3). The mylohyoid nerve was observed to travel within the mandibular canal in the 5th, 6th and 7th bony slices (Figs. 2, 3). After leav-

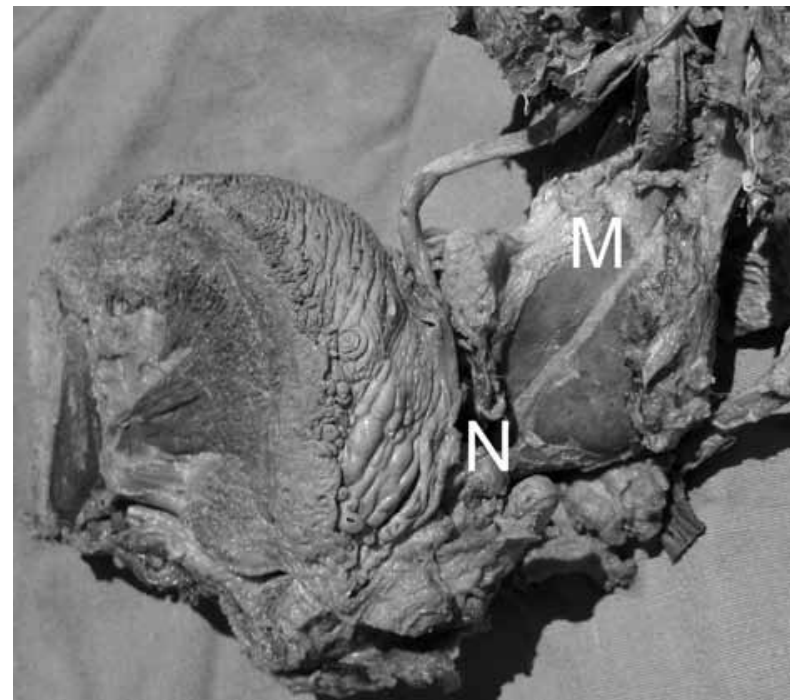

Fig. 1. Lingual view of right hemi-mandible. Mylohyoid nerve (N); mandibular canal $(M)$.
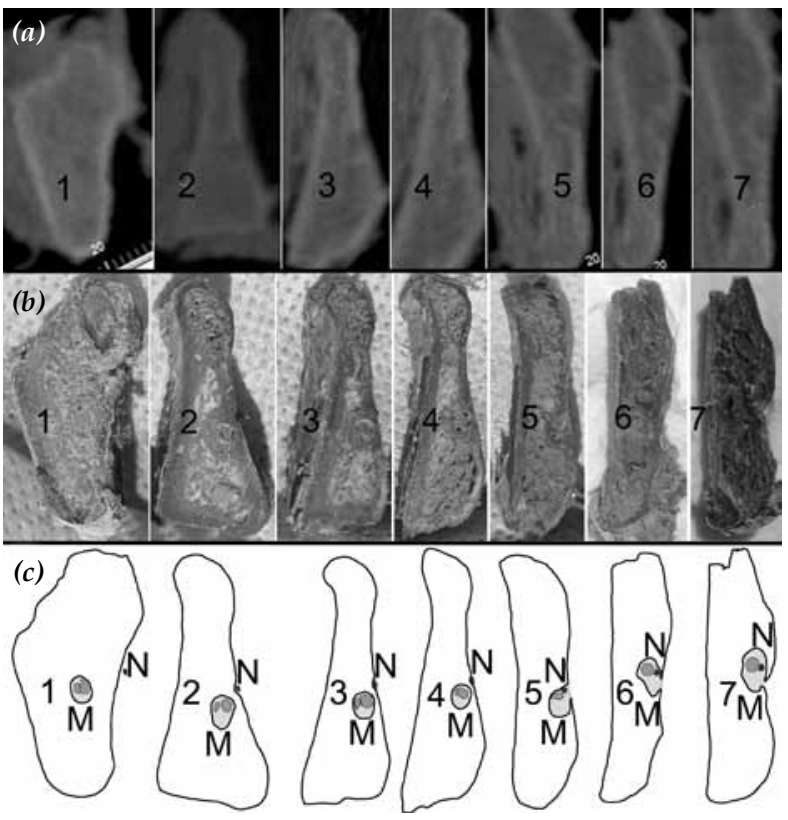

Fig. 2. Right hemi-mandible. (a) Dental cone-beam computed tomography images. (b) 8 serial sections and 7 bony slices (anterior view). (c) Schematic drawing of 7 bony slices. Bony slices (1-7); mylohyoid nerve (N); mandibular canal (M).

ing the foramen ovale, the mandibular nerve separated into buccal, lingual, inferior alveolar and mylohyoid branches. The mylohyoid nerve was formed by the association of two different branches, one splitting off from the mandibular nerve and the other from the inferior alveolar nerve. The mylohyoid and inferior alveolar nerves subsequently separated (Fig. 4), and at distance of $14.1 \mathrm{~mm}$ away from their separation point, the two nerves together entered the mandibular canal from the mandibular foramen (Fig. 5a, b). The mylohyoid nerve

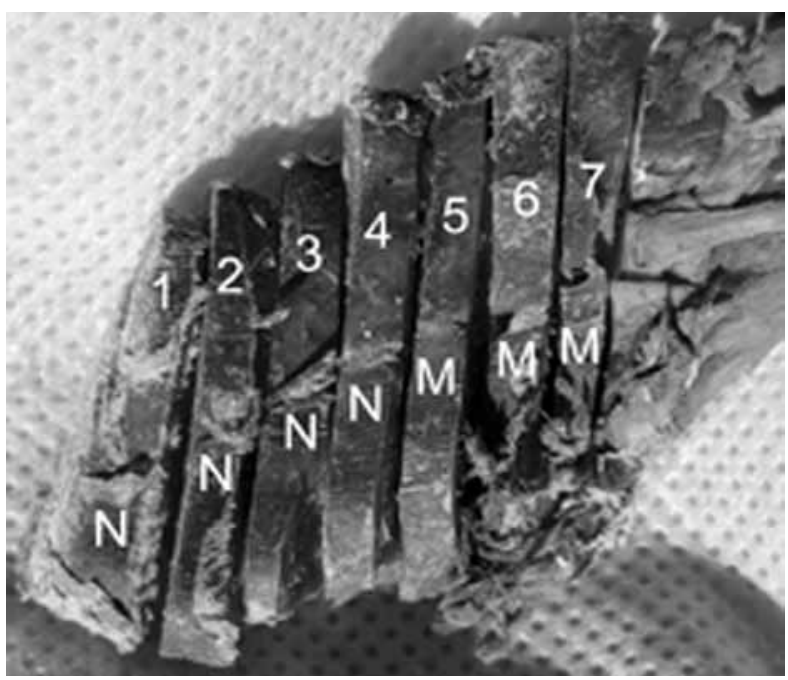

Fig. 3. Lingual view of right hemi-mandible. 8 serial sections and 7 bony slices. Bony slices (1-7); mylohyoid nerve (N); mandibular canal $(M)$. 


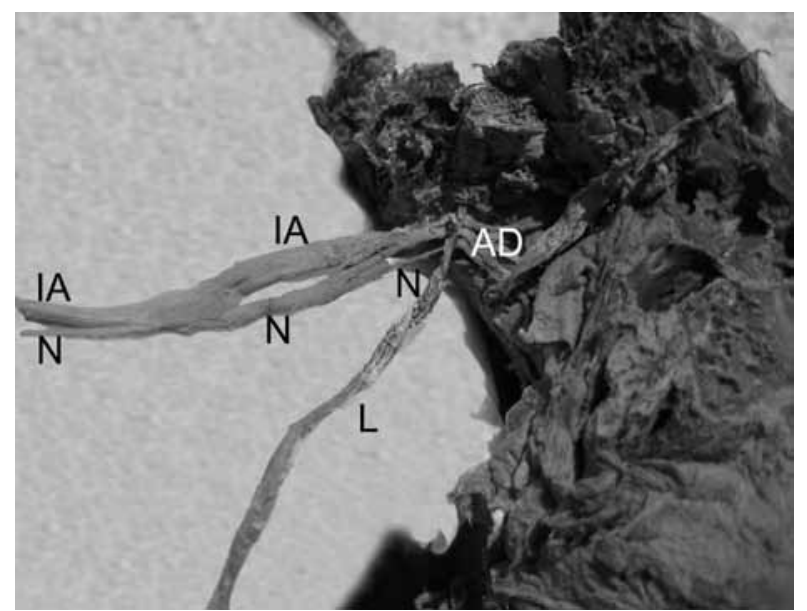

Fig. 4. Branches of the mandibular nerve after it leaves the foramen ovale. Anterior division of the mandibular nerve $(A D)$; lingual nerve (L); inferior alveolar nerve (IA); mylohyoid nerve $(N)$.

then exited the canal after running within the canal for a distance of $24.3 \mathrm{~mm}$ (Fig. 5c, d). Similar sectioning and imaging of the left side of the mandible showed the mylohyoid nerve did not enter the mandibular canal on the left side.

\section{DISCUSSION}

This case study documents the route of the mylohyoid nerve within the mandibular canal. Arensburg et al. ${ }^{[2]}$ reported that out of a total of 390 dry hemi-mandibles, $83.6 \%$ had a mylohyoid groove, whereas this groove was partially or fully converted to a bony canal in $16.4 \%$. Bennett et al. ${ }^{[3]}$ observed the mylohyoid nerve to travel through either a mylohyoid groove or a mylohyoid canal. The ossification of the mylohyoid groove may best be explained by the membrane's embryologic origin from the Meckel's cartilage close to the canal.

Clinicians should be aware of the possible anatomical variations of the mylohyoid nerve and of complications that may arise in cases where the nerve travels within the mandibular canal. In such cases, the mylohyoid nerve can be damaged during surgical procedures of the mandible, including osteotomies and salivary gland operations. The anatomical and radiographic findings of a mylohyoid nerve traveling within the mandibular
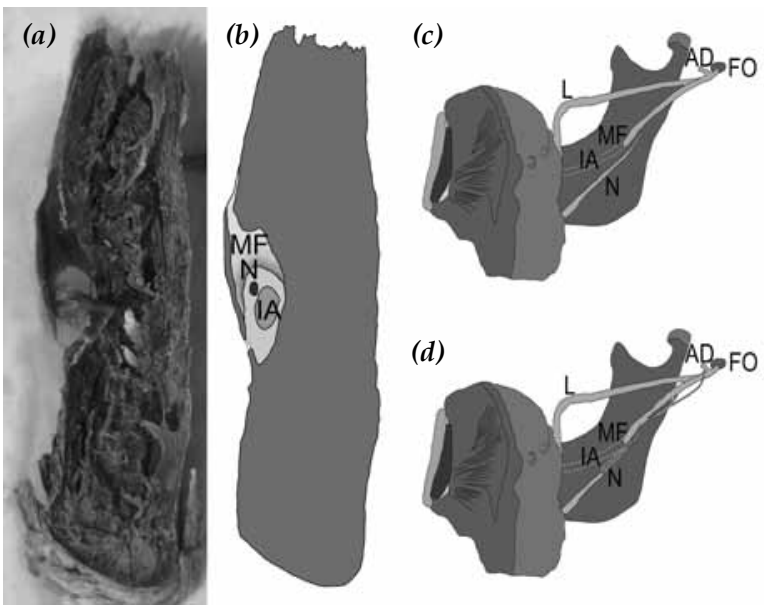

Fig. 5. (a) Posterior view of Slice No.7 (b) Schematic drawing of Slice No.7. Formation and course of mylohyoid nerve (schematic drawing). (c) Normal course. (d) Present case. Foramen ovale (FO); mandibular foramen $(M F)$; anterior division of the mandibular nerve $(A D)$; lingual nerve $(L)$; inferior alveolar nerve (IA); mylohyoid nerve $(N)$.

canal that are highlighted in this case report suggest that further research is necessary to obtain more detailed knowledge regarding variations of position and course of the mylohyoid nerve.

\section{REFERENCES}

1. Gray H, Williams PL, Bannister LH, editors. Gray's anatomy: the anatomical basis of medicine and surgery. Edinburgh: Churchill Livingstone; 1995.

2. Arensburg B, Nathan H. Anatomical observations on the mylohyoid groove, and the course of the mylohyoid nerve and vessels. J Oral Surg 1979;37:93-6.

3. Bennett S, Townsend G. Distribution of the mylohyoid nerve: anatomical variability and clinical implications. Aust Endod J 2001;27:109-11.

4. Guyot L, Layoun W, Richard O, Cheynet F, Gola R. Alteration of chin sensibility due to damage of the cutaneous branch of the mylohyoid nerve during genioplasty. J Oral Maxillofac Surg 2002;60:1371-3.

5. Adjei SS, Hammersley N. Mylohyoid nerve damage due to excision of the submandibular salivary gland. Br J Oral Maxillofac Surg 1989;27:209-11.

6. Marinho RO, Tennant CJ. Paresthesia of the cutaneous branch of the mylohyoid nerve after removal of a submandibular salivary gland. J Oral Maxillofac Surg 1997;55:170-1.

7. Rallis G, Mourouzis C, Zachariades N. A study of 55 submandibular salivary gland excisions. Gen Dent 2004;52:420-3. 